\title{
ELT in Algeria: The Hegemony of the Teach-to-the-Test Approach
}

\author{
Smail Benmoussat ${ }^{1} \&$ Nabil Djawad Benmoussat ${ }^{1}$ \\ ${ }^{1}$ Department of English, Faculty of Letters and Languages, University of Tlemcen, Algeria \\ Correspondence: Smail Benmoussat, Department of English, Faculty of Letters and Languages, University of \\ Tlemcen, Algeria.
}

$\begin{aligned} & \text { Received: February 23, } 2018 \\ & \text { Accepted: March 20, } 2018 \quad \text { Online Published: May 14, } 2018 \\ & \text { doi:10.5539/ells.v8n2p63 }\end{aligned}$ URL: https://doi.org/10.5539/ells.v8n2p63

\begin{abstract}
The late 1970s witnessed the emergence of a widespread movement that expressed its reaction against the approaches and methods which focused too much on the teaching of discrete items. That was clearly stated by applied linguists, teachers and educators who virtually all contended that traditional methods which used translation and systematic grammatical analysis left the language learners little time to practice the spoken language and to enhance their communicative abilities. As a direct outcome of such reaction, a concern developed to make foreign language teaching, not least English "communicative". Communicative Language Teaching, henceforth CLT, has attracted a worldwide interest. Regrettably, seldom is testing processed "communicatively"; most Algerian EFL teachers prefer to cling tenaciously to the teach-to-the-test approach "principles". This preference is closely related to the notion of "achievement" which means nothing more than giving the opportunity to the learner to score well on standardized tests and high-stakes exams. This dimension indicates the extent to which the teach-to-the-test approach acts as the "sword of Damocles" hanging over ELT in Algeria converting EFL keep-pace learners into set-the-pace swots.
\end{abstract}

Keywords: discrete items teaching-testing, Communicative Language Teaching, teach-to-the-test approach

\section{Introduction}

Although Algeria was one of the pioneers in implementing CLT, little was done to prepare the schools for the necessary changes and to provide the appropriate conditions required by the communicative approach. English classrooms rarely met the criteria of purposefulness and contextualization that defined CLT tasks at the level of the intended aims and objectives. Such a situation was due to the pedagogical constraints, i.e., the incongruence between the intended and implemented syllabus. What is more, the communicative approach has always been controversial in Algerian educational institutions in the sense that it challenges the traditional conceptions of good teaching and learning, i.e., fluency at the expense of accuracy. Worse still, many teachers, especially the more experienced, still do point to communication-based teaching as a reason for declining English standards in Algeria and in many parts of the world.

Needless to recall, in the 1980s, CLT became a buzz term and a cliché which was used here and there rightly and wrongly, most of the time, with no precise perception in the principles it embodied in popular literature and common parlance among EFL teachers. This is another way of saying that this approach to language teaching has become so over-used that it has begun to lose its meaning. The following is an attempt to give a list, a non-exhaustive one, of the characteristics underlying communicative language teaching. In sum then, and according to Larsen-Freeman (1986), CLT is characterized by the focus on communicative competence, orientation towards learner-centeredness, emphasis on the role of teachers as facilitators and providers of a secure, non-threatening atmosphere, introduction of group activities, and finally, use of authentic materials. A related point worth noting here is that originally, the term "communicative competence" was used to refer to what a speaker needs to know in order to communicate effectively in culturally significant situations (Hymes, 1974). It has become the rallying call of CLT. The Council of Europe (2001, p. 9) defines it as "a person's ability to act in a foreign language in a linguistically, socio-linguistically and pragmatically appropriate way."

\section{CLT: Western-Thought Package}

One of the main criticisms one can make to this approach is that it is derived from Western models and implemented on the basis of concept developed in the Anglo-American applied linguistic context, i.e. the provision of a supportive and consolidating linguistic environment. However, in its original version it has been 
uncritically adopted to the Algerian foreign language teaching context, a context characterized by a serious lack of a supportive and consolidating linguistic environment. The problem with CLT was not grounded in the local context and educational realities: it was very much a "Western-thought package". Today many EFL teachers convincingly note that CLT should be the model-approach, the one-size-fits all, but as McKay (2003, p. 15) argues: "CLT has been largely promoted in ELT in Inner Circle countries and in private English language institutes in Outer and Expending Circle countries". We should make it clear, however, that the worldwide spread of English has been sorted out into three concentric circles: the inner circle, i.e., the norm-providing countries such as the UK, the USA, Canada, Australia and New Zealand. The outer or extended circle, i.e., norm-developing countries such India, Pakistan and the other former British colonies. The expanding circle, i.e., norm-dependent countries such as China, Russia, and the countries where English is taught as a foreign language (Kachru, 1985).

It goes without saying that, a successful and promising educational policy of language teaching, not least English due to its worldwide recognition as a global language, requires a great deal of institutional support in terms of class size, classroom materials, teacher training and other related educational inputs. Overall, the communicative approach trend did not equip teachers who were driven by its urge to change with either theoretical or material tools for handling various pedagogical situations in accordance with the principles underpinning communicative language teaching. What is more, Swan $(1985$, p. 82) in his article $A$ critical look at the communicative approach (2), draws a cogent distinction between what he qualifies as "real-life use of language" and "real-life fallacy" and notes that: "The classroom is not the outside world, and learning a language is not the same as using language. A certain amount of artificiality is inseparable from the process of isolating and focusing on language items for study".

Since its inception in the late 1970s, the communicative approach has been gaining ground in many language classrooms in various parts of the world. Communicative Language Teaching developed as a sound substitute to the traditional methods and approaches of teaching grammar and culture. The rationale underlying this approach is that the purpose of learning a language is to take part in communication acts. It is commonly agreed that the approach is learner-centred and relies heavily on the learner's language resources, which reflect the home culture. In the context of English language learning in Algeria, the approach would mean the reliance on Algerian resources.

\section{Glocalization of CLT}

The shift from using English language teaching materials imported from Britain to using home-made ELT textbooks is an indication of the processes of localization that come along the communicative approach (Tam \& Weiss, 2004). A process of glocalization has been steadily gaining ground. Glocalization, a porte-manteau word consisting partly of globalization and partly of globalization, is the adaptation of international products around the particularities of a local culture in which it is sold. The process allows the integration of local markets. It denotes the simultaneity, i.e., co-presence of both universalizing and particularizing tendencies (Robertson, 1995). It is commonly accepted that language use depends on the culture it embodies, i.e., the cultural context of language. Such an assertion calls into question the notion of culture, home culture vs. target culture. Put differently, which culture is required to develop communicative competence? The British culture which is based on an appraisal of the Western values and ways of life, or the local culture the learner's culture which represents a reservoir of ideas and resources serving the context of communication in language learning activities.

From a pedagogical standpoint, the production of home-made ELT textbooks that draws on the Algerian-culture makes the teaching and learning of English much easier for both the teacher and learner respectively; the cultural dimension has been pushed to the margins and no more is the source of long and detailed and useless explanations. The in-class language activities are made more manageable with the elimination of the cultural component that symbolizes the target culture. This process of "de-Anglicization" highlights the deliberate reduction of the cultural load in terms of content and character in home-made EFL textbooks. The idea is based on the premise English, as a growing global language, does not belong to any one culture and as such should be independent from its nationality-bound cultural setting. The belief underlying this censorial and authoritarian approach to EFL teaching is to reduce the "unwanted side-effects" of English Language Education. Hence, learning a language becomes a mastery of a set of language skills. A slight distinction, yet significant, is made in terms of English Language Teaching and English Language Education. Both might be semantically and didactically equivalent, but in our very specific context, the use of English Language Education in an attempt to be truly educative and to give a broader value and meaning to the language learning process. Language teaching can claim to have social significance, and to contribute to the student's general education by introducing them to cultures other than their own. 
Although the rhetoric of the General Inspectorate of English has always been the development of the practical communication skills, this has rarely been reflected in the classroom where emphasis has been on the development of the reading comprehension skills, vocabulary building and mastery of the structural patterns for the sole purposes of passing the Baccalaureate exam. The Baccalaureate is, essentially, a high-stakes secondary school-leaving exam whose outcome has life-changing implications as it allows third-year secondary education students to embark on tertiary studies, i.e., an entrance-like visa to university and higher education institutes. As a corollary to that, it should be posited that high-stakes exams are so important in the eyes of many stakeholders in the sense that their results, as Madaus (1988, p. 87) notes: "are seen, rightly or wrongly, by students, teachers, administrators, parents, or the general public, as being used to make important decisions that immediately and directly affect them". Much like British A-Levels or American high school diplomas, the Baccalaureate allows Algerian and international students to obtain a standardized qualification, typically at the age of 18. From an elitist viewpoint, the Baccalaureate is supposed to act as a roadblock to mediocrity and is employed as a selection instrument for tertiary education. In many cases, it has a beneficial washback effect on education due to the fact that it acts as a stimulus for studies. Washback or backwash, a term now commonly used in the testing literature, refers to the influence of testing on teaching and learning (Alderson \& Wall, 1993). Alan Davis, the doyen of British language testing, frequently used the term washback and I do not recall him ever using backwash... to clarify the distinction between the terms backwash and washback: there is none. The only difference is that if somebody has studied at the University of Reading, UK, where Arthur Hughes used to teach, they are likely to use the term backwash. Hughes (2003) states simply that: "the effect of testing on teaching and learning is known as backwash" (p. 1). If they have studied language testing anywhere else, but especially in Edinburgh or Lancaster in the UK, they will almost certainly use the term washback (Alderson, cited in Cheng \& Watanabe, 2004, pp. xi-xii). However, Andrews (1994, p. 67) comments on the backwash versus washback nomenclature. Based on his own review of the literature, he comments that: "in general education literature, the favoured term to describe this phenomenon is "backwash", while in language education there seems to be a preference for "washback"”.

\section{The Baccalaureate and the Teach-to-the-Test Approach}

The Baccalaureate examination, as an achievement test, plays an important role in the Algerian education system at large. It usually takes place in June. This end-of-year period is a very stressful for stakeholders, mainly students, teachers, school administrators and parents. Since its inception in 1963, the Baccalaureate examination has always been a lever for change to initiate educational reforms in an effort to establish academic standards and a more or less reliable source of information on educational outcomes to external stakeholders. Its preparation starts early in the school year, sometimes even a few years beforehand. It has a reputation for being a thorough summative assessment. Tests are frequently used as a means to engineer innovation, to steer and to guide the curriculum (Alderson, 2004). Tests are, all too often, intended as levers for change (Pearson, 1988). The challenge resides in how to make such mechanism consolidate and reinforce the teaching and learning of skills that are conducive to a betterment of the education system at large. What is more, the over importance assigned to the bureaucratic nature of the Baccalaureate in the Algerian education system has paved the way for the emergence of a new philosophy. This philosophical conception is rendering teachers even more cynical about the rate of success in the Baccalaureate exam, and devising ways of turning it to productive account for teachers and learners.

This cynical dimension would lead us to touch on another aspect of the teach-to-the-test approach: the coaching services that are offered outside school time and school walls by teachers. These so-called extra remedial lessons, oriented chiefly towards practicing exam techniques have turned to become commonplace and a very trendy form of outside-schooling. Students spend evenings, weekends, and even holidays preparing for the Baccalaureate exam in teachers' homes, or even in garages. The benefits of such a compensatory teaching are wide-range: the number of students is very limited, the teacher explains every single word or structure in Arabic or in French, he goes through the exercises that were done in the classroom and the pupil has all the chances to succeed. That's an extra to teachers to make ends meet. It goes without saying that this type of supplementary education costs a great deal of money, and yet students' families willingly or unwillingly try to "keep up with the Joneses", to use an appropriate idiomatic expression and the word "achievement" means nothing more than scoring well on standardized tests and high-stakes exams.

Many EFL inspectors report that during the in-service training sessions, teachers, as researchers, show great interest and enthusiasm in new methodologies, but once in class, as practitioners, they continue sticking to old methods of teaching. It is important to note that teachers may hold positive attitudes towards a teaching innovation, yet their willingness to actually implement it could be another matter. As English (1992) stated well: 
"the end point of educational change, classroom change, is in the teachers' hands. When the classroom door is closed and nobody else is around, the classroom teacher can then select and teach almost any curriculum he or she decides is appropriate irrespective of reforms, innovations, and public examinations" (Quoted in Cheng \& Curtis, 2004, p. 17).

\section{Communicative Language Testing}

Communicative language testing is intended to provide the teacher with information about the learners' ability to perform in the target language in certain context-specific tasks. It is commonly agreed that, by the mid- $80 \mathrm{~s}$, the language-testing field had begun to focus on designing communicative language-testing tasks (Brown, 2003, p. 10). However, there is an overt and manifested mismatch between teaching practices and testing activities. In this very specific context, Inbar-Lourie (2008, p. 289) notes that: "The move from an atomized view of language knowledge to what is known as communicative competence, and to communicative and task-based approaches to language teaching has accentuated the incongruity of existing assessment measures. Calls for matching language learning and evaluation have been repeatedly made since Morrow (1979) urged language testers over three decades ago, to bridge the gap between communicatively focused teaching goals and the testing procedures used to gauge them".

As a case in point, speaking, the most active productive skill and the most common focus of Communicative-oriented language teaching and the hallmark par excellence of CLT, is not tested at all. That's a fundamental paradox in the sense that the communicative approach, as its name implies, originates from the theory of language as communication and the main objective of language teaching activities is to develop communicative competence as put forward first by Hymes (1972), then elaborated by Canale \& Swain (1980), extended by Canale (1983), and revisited by Bachman (1990), and Bachman \& Palmer (1996). Understanding the different components that come into play in the elaborate model of communicative competence is necessary and helpful for developing communicative language test.

Arguably, most teachers claim to teach "communicatively" in one way or another, and it is hardly surprising that no one wishes to be called a non-communicative teacher (Karavas-Douglas, 1996, p. 1). In the same line of thought, Richards (2007, p. 58) notes that: "Perhaps the majority of language teachers today, when asked to identify the methodology they employ in their classrooms, identify "communicative" as the methodology of choice". In the context of English language teaching, the label "non-communicative teacher" may be debasing and may be taken to mean a teacher who is mindless of his or her duties vis-à-vis his or her learners. Savignon (2002) confirms the fact that there is a low correlation between what teachers state and what they do in terms of their classroom practices. CLT has had its heyday in the 1980s and was viewed as a banner under which language teachers would march. However, many teachers have incomplete and imprecise notions of what CLT entails and what a communicative language test should incorporate. In overall terms, one can call into question the teacher training scheme, both pre-service and in-service.

With this presumption in mind, we may allow ourselves to formulate the following questions: Have our teachers been sufficiently trained to teach and to assess along the lines of the communicative approach? Have they been properly and adequately prepared to lend themselves to the quality label of communicative language teachers? While most teachers confess to make their teaching draw on the principles developed in the literature of CLT, however, in practice they tend to be much more traditional and structural to the extent that they measure their progression in the programme in purely grammatical terms instead of notional-functional categories, an easy way to spot their way on the teaching/testing continuum. This reflects that there is somewhere some form of resistance to change that is deliberately expressed and manifested by teachers, not least long-experienced teachers, let alone many novice teachers whose pre-service training leaves a lot to be desired.

A central tenet of communicative language testing is that the tasks are designed to represent authentic activities which test learners are to be expected to encounter in the real world outside the classroom. Brown (2005) identifies five requirements that make up what is to be called a communicative test. The requirements in question are: 1) meaningful communication, 2) authentic situation, 3) unpredictable language input, 4) creative language output, and 5) integrated language skills.

Unlike communicative language tests, discrete point testing, based on an analytical view of language, assumes that knowledge of the language system can be divided into a number of independent elements: grammar, vocabulary, spelling and punctuation, pronunciation, intonation and stress. These can be tested through the following formats: Phoneme recognition, Yes/No answers, True/false statements, Spelling, Word completion, Grammar items and Multiple Choice Questions. Discrete point tests have been severely criticized for handling only recognition knowledge and facilitating guessing and cheating. The discrete point approach has always had 
the lion's share in the language tests in general and the Baccalaureate EFL exam in particular. Each test item is devised to give clues about the candidate's mastery of a particular point of language. It is important to know that teachers' conviction to use this approach is due to two main reasons: one pedagogical and the other societal. The pedagogic dimension closely relates to the fact that virtually all teachers point out the overloaded curricula for which they are bound up to cover in due time. This time constraint leads teachers to engage in a selection of only those items that likely to feature prominently in exams rather than to teach effectively and with pace according to their learners degree of intake and assimilation. The societal dimension is due to the fact that both parents and the academic institution give too much importance and great value to the result obtained by their students. In other words, and in terms of accountability, the education institution in general and teachers in particular are judged in relation to their students' success and achievement in exams, not least high-stakes exams, such as the Baccalaureate exam. Since independence in the early 1960s, scores obtained in standardized tests have served as a "benchmark" to compare and rank educational institutions throughout the country. In sum then, standardized testing is still regarded as a large-scale measure of schools effectiveness.

\section{Conclusion}

Admittedly, the main advantage of the discrete point tests is that they yield easily-quantifiable data, and can be accurately and objectively marked even by mechanical scanning methods. However, one of the main drawbacks of the approach is that an atomistic approach to test design depends utterly on the assumption that knowledge of the elements of language is equivalent to knowledge of the language (Morrow, 1981, p. 11). Such a view does not hold true in the context of communicative language testing and discrete point testing is no longer felt to provide a sufficient measure of language ability. What matters most is not how a language works, but rather the ability to use it in meaningful communication and authentic situation in an integrative way.

The implementation of communicative language test has always been viewed with a purely positive ring to it. Few educationalists and test designers have grown dissatisfied with communicative language testing. Most of the criticisms made to communicative language testing are directed towards the form. Communicative tests virtually incorporate real-world situations where the language learners experience and strive to produce language creatively with an integrated approach of the language skills. They help teachers measure their learners' language ability more accurately. They also help learners become familiar with some testing types they are likely to encounter when taking tests that are internationally acknowledged have a worldwide fame, such the TOEFL (Test of English as a Foreign Language) or the IELTS (International English Language Testing System). Finally, implementing communicative tests represents a radical shift away from the oft-grammar based traditional tests.

\section{References}

Alderson, J. C., \& Wall, D. (1993). Does Washback Exist? Applied Linguistics, 14, 115-129. https://doi.org/10.1093/applin/14.2.115

Andrews, S. (1994). The Washback Effect of Examination: its impact upon curriculum innovation in English language teaching. Curriculum Forum, 4(1), 44-58.

Bachman, L. F. (1990). Fundamental Considerations in Language Testing. Oxford: Oxford University Press.

Bachman, L. F., \& Palmer, A. S. (2010). Language Testing in Practice. Oxford: Oxford University Press.

Brown, H. D. (2005). Testing in Language Program. New York: McGraw-Hill.

Canale, M., \& Swain, M. (1980). Theoretical Bases of Communicative Approaches to Second Language Teaching and Testing. Washington, D.C. Center for Applied Linguistics.

Cheng, L., \& Curtis, A. (2004). Washback or Backwash: a review of the impact of testing on teaching and learning. In L. Cheng, Y. Watanabe, \& A. Curtis (Eds.), Washback in Language Testing: research contexts and methods. London: Lawrence Erlbaum Associated Publishers.

Cheng, L., \& Watanabe, Y. (2004). Washback in Language Testing: research contexts and methods. London: Lawrence Erlbaum Associated Publishers.

Crystal, D. (1989). The Cambridge Encyclopedia of Language. Cambridge: Cambridge University Press.

Hughes, A. (2003). Testing for Language Teachers. Cambridge: Cambridge University Press.

Inbar-Lourie, O. (2008). Language Assessment and Culture. In N. H. Hornberger (Ed.), Encyclopedia of Language and Education (2nd ed.). Berlin: Springer. https://doi.org/10.1007/978-0-387-30424-3_182

Hymes, D. (1974). Foundations in Sociolinguistics: an ethnographic approach. Philadelphia: University of Philadelphia Press. 
Karava-Douglas, K. (1996). Using Attitude Scales to Investigate Teacher's Attitudes to Communicative Approach. ELT Journal, 50(3), 181-198.

Kachru, B. B. (1986). The Alchemy of the English Language. Oxford: Oxford University Press.

Morrow, K. (1979). Communicative Language Testing: revolution or evolution? In C. K. Brumfit \& K. Johnson (Eds.), The Communicative Approach to Language Teaching (pp. 143-159). Oxford: Oxford University Press.

Morrow, K. (1981). Communicative Language Testing: evaluation or revolution? In J. C. Alderson, \& A. Hughes (Eds.), Issues in Language Testing. ELT Documents, 11(1). London: The British Council.

Mckay, S. L. (2012). Toward an Appropriate EIL Pedagogy: Re-examining Common ELT Assumptions. International Journal of Applied Linguistics, 13(1). San Francisco State University.

Richards, J. C. (2007). Beyond Training. Cambridge: Cambridge University Press.

Rivers, W. M. (1981). Teaching Foreign Language Skills. Chicago: The University of Chicago Press.

Robertson, R. (1995). Glocalization: Time-Space and Homogeneity-Heterogeneity. In M. Featherstone, S. Lash, \& R. Robertson (Eds.), Global minorities (pp. 25-44). London: Sage. https://doi.org/10.4135/9781446250563.n2

Savignon, S. J. (2002). Interpreting Communicative Language Teaching: contexts and concerns in teacher education. New Haven: Yale University.

Swan, M. (1985). A Critical Look at the Communicative Approach. ELT Journal, 39(1). https://doi.org/10.1093/elt/39.1.2

Tam, K., \& Weiss, T. (2004). English and Globalization: perspectives from Hong Kong and Mainland China. Hong Kong: The Chinese University Press.

Widdowson, H. G. (1979). Teaching Language as Communication. Oxford: Oxford University Press.

Wilkins, D. A. (1979). Notional Syllabuses. Oxford: Oxford University Press.

\section{Copyrights}

Copyright for this article is retained by the author(s), with first publication rights granted to the journal.

This is an open-access article distributed under the terms and conditions of the Creative Commons Attribution license (http://creativecommons.org/licenses/by/4.0/). 